Сергій КУЦЕНКО,

orcid.org/0000-0002-8020-2141

кандидат історичних наук

викладач кафедри всесвітньої історії

та методик навчання

Уманського державного педагогічного

університету імені Павла Тичини

(Украӥна, Умань)

kutsenka7@gmail.com

\title{
СУЧАСНІ ТЕНДЕНЦІЇ В РОЗРОБЦІ СТРУКТУРИ, КОНТЕНТУ ТА ВЕБ-ДИЗАЙНУ МУЗЕЙНИХ САЙТІВ
}

В статті розглядаються питання використання мережі Інтернет як ефективного середовища для популяризаиії музейних колекиій. Проаналізовано особливості створення музейного сайту, щзо вимагає адаптаџіiі $і$ доопраџювання під музейну специфіку. Автором статті наведено деякі практичні рекомендації щзоо створення та супроводження власного музейного Інтернет-ресурса, дотримання яких допоможе створити цікавий для відвідування музейний веб-сайт. Звернуто увагу на здобутки в інформаційній діяльності українських музеїв щцодо створення та використання електронних інформаційних ресурсів. caŭmy.

Ключові слова: музей, сайт, Інтернет, контент, оцифрування, комунікація, веб-дизайн, структура

\author{
Sergiy KUTSENKO, \\ candidate of Historical Sciences \\ lecturer of World History \\ and Teaching Methods Department \\ Pavlo Tychyna Uman \\ State Pedagogical University \\ (Ukraine, Uman) \\ kutsenka7@gmail.com
}

\section{CURRENT TRENDS IN DEVELOPING STRUCTURE, CONTENT AND WEB DESIGN OF MUSEUM SITES}

The research is focused on changing the museums tasks and opportunities in condition of the appearance of the Internet as global communication resource. More and more museums make decisions to support their websites to expand providing information about themselves and attract new visitors. As noted, the site is not only an important element of the image of the museum, which suggests its progress in terms of the development of modern information technology. This is a step towards creating an electronic clone of the museum, its virtual image on the Internet. Therefore, forming it, it is important to predict in advance the main trends of development both real institution and its electronic copy. Over the two last decades the introduction of Internet culture in our society has appeared to review the principles of creating a website for any institution. It is noted, until recent time, the creation of a site business-card meant a breakthrough in the activities of the museum, therefore, they did not pay particular attention to what specific information the site contains, whether it is convenient to navigate, whether it has a user-friendly interface and whether it meets all the questions that may arise at potential visitor of the institution. The main idea of the article is to consider the issues relevant for the Ukrainian museum, which should be the modern site of the museum and how to attract new visitors.

The main task was that information about any museum was available on the World Wide Web and could be found by standard search systems. Today the situation is gradually changing since a large amount of information on the Internet makes more actual not the task of making information content, but a vivid presentation and quality selection of materials. The sources of information begin to compete with each other, and eventually the winner becomes most informative and professional site but convenient and easy to use Internet resource. 
It is stated that one of the difficulties for the museum team is that the development of scientific and technological progress is not static: the appearance, navigation of various types of Internet resources is constantly improving, so the sites, created 5-10 years ago, could may look out of date and do not satisfy increased inquires of modern users. Therefore, the question is appeared: how not to lose the right point in the era of change. What choose as the starting point during creating a museum's website? How to organize the site structure so that its sections are ergonomically combined and easily accessible, easy to use and at the same time attractive in terms of design?

Great attraction to the museum sites is in the usage of game elements. For a more voluminous representation of museums, sites include architectural scans, interactive floor plans, and three-dimensional graphics. The largest museums in the world have been using the virtual exertion technology also.

It may be concluded, that the main problems of the representation of the museum on the Internet are the choice of adequate forms of publication museum information, absence of regular filling of the site-pages, outdated information, low-quality design.

Keywords: museum, site, virtual tour, Internet, content, digitization, communication, web design, site structure.

Постановка проблеми. Формування єдиного світового інформаційного простору відкриває нові можливості для глобального інформаційного обміну, що є одним із пріоритетних завдань створення інформаційного суспільства. Найбільш яскравим виявом кардинальних змін у цій сфері $\epsilon$ створення Інтернет-ресурсів, які мають величезний потенціал в області розширення доступу до інформації. Особливе значення Інтернет-ресурси мають для вирішення проблем надання найширшій аудиторії доступу до культурного контенту. Стрімке зростання аудиторії Інтернет-користувачів закономірно визначає прагнення установ культури, зокрема музеїв, до створення власних сайтів. Активізація роботи у цьому напрямку закономірно породжує безліч питань, пов'язаних $з$ пошуком ефективних шляхів до створення сайту, контент якого буде цікавим для потенціальної аудиторії, а кожна веб-сторінка не лише привертатиме увагу потенційних Інтернет-користувачів своїм веб-дизайном, але надаватиме їм повну і точну інформацію про діяльність музею.

Аналіз досліджень. Проблемою створення та наповнення музейних сайтів займалися Алдохін А. (Алдохін, 2010), Гендина Н. (Гендина, 2010), Заславец Н. (Заславец, 2009), Колкова Н. (Колкова, 2010), Легеченко М. (Легеченко, 2009), Самаковська А. (Самаковська, 2010, 2012) та ін. До недавнього часу дана тематика українськими науковцями практично не досліджувалася. Серед вітчизняних науковців проблему розробки концепції та технології створення музейного сайту досліджували Мина Ж. (Мина, 2016), Огоновська I. (Огоновська 2016), Терлецька Х. (Терлецька, 2016), Яцечко-Блаженко Т. (Яцечко-Блаженко, 2016). 
Мета статті. Автор поставив собі за мету описати особливості розробки структури та типової моделі контенту музейних сайтів.

Виклад основного матеріалу. Перш ніж створювати власний Інтернетресурс необхідно створити робочу групу із колективу установи, яка й буде займатися проблемою розробки проекту майбутнього сайту. Необхідно дотримуватися певних правила, що сайт створюється саме для потенційної аудиторії музею, а не для самих музейних фахівців, тому інтереси користувачів повинні бути, в першу чергу, враховані при розробці структури та інформаційного наповнення Інтернет-ресурсу. Перед створенням сайту слід провести детальний аналіз інформаційних потреб його потенційних відвідувачів. Першим кроком діяльності робочої групи має стати розробка плану, в якому чітко буде розписано, що і де буде розташовуватися.

Планування створення музейного сайту передбачає обговорення ряду важливих питань:

1. Завдання й цілі сайту?

2. Хто буде головним користувачем?

3. Яким буде веб-дизайн?

4. Хто буде займатися підтримкою і технічним обслуговуванням сайту?

5. Х Хо буде відповідати за складання і відбір матеріалів (редагування текстів, фотозйомка та обробка зображень (Заславец, 2009: 65).

Під поняттям структура сайту розуміється внутрішній устрій веб-ресурсу, його основа («скелет»), розташування сторінок, розділів, підрозділів, додаткових джерел. Структура сайту - це логічно побудована зв'язка хаотичного скупчення інформації, поєднана єдиним веб-дизайном, посиланнями і стилем. Це також і систематизація всієї інформації по розділах сайту під один зразок, об'єднуючим механізмом тут є головне меню сайту, яке виступає основним навігаційним засобом Інтернет-ресурсу.

Контент - це інформаційне наповнення сайту (переважно в текстовій формі), також це можуть бути фото, картинки, аудіо та відеоматеріали. 
Головною закономірністю розміщення контенту $є$ його унікальність. До інформації, що розміщується на офіційному сайті установи, відноситься інформація про проведені заходи, виставки, семінари, конкурсні програми, проекти, події, фотоматеріали, відеоматеріали, опис фондів, графік роботи закладу, нормативні акти, державне завдання і звіти про його виконання, звіти про діяльність, коментарі відвідувачів сайту тощо. Підготовку інформації для розміщення на сайті установи здійснюють співробітники структурних підрозділів музею, користувачі сайту. Інформація, передана співробітником установи, користувачем веб-сайту для публікації, повинна бути перевірена керівником структурного підрозділу установи, адміністратором сайту i керівником музею на актуальність і якість матеріалу, стилістику, синтаксис і граматичну складову. Щоб зацікавити користувачів інформація повинна бути представлена в зручному вигляді, бути яскравою, зрозумілою, конструктивною i схематичною. Найбільша проблема українських музеїв у цьому сегменті полягає в тому, що стиль тексту не відповідає сучасним вимогам читача - він $€$ дуже специфічним, тому автори часто зловживають академічним стилем. Часто змістовна частина сайтів українських музеїв $\epsilon$ цитатами співробітників музеїв, або робіт вчених, які досліджували тематику, пов'язану 3 діяльністю музею. Вони рідко намагаються захопити предметом дослідження і розповісти його історію на науково-популярному рівні. Всі наукові тексти, праці співробітників музею, присвячені його діяльності, повинні розміщуватися в окремому розділі ( Гендина, Колкова, Алдохина, 2010: 88).

Вся перевірена і схвалена інформація публікується на офіційному сайті установи. Відповідальність за достовірність та своєчасність надання інформації покладається на завідуючих секторами та відділами. Відхиляється від публікації:

- інформація, що містить ознаки дискримінації за ознаками статі, віку, раси, національності, мови, громадянства, соціального, майнового або сімейного стану, політичних чи релігійних уподобань; 
- інформація, що містить загрозу вчинення протиправних дій (бездіяльності), щодо яких законодавством встановлено юридичну відповідальність;

• відомості, що становлять державну та іншу таємницю, яка охороняється законодавством;

- інформація, що містить образливі вислови, які принижують честь, гідність громадянина;

- некоректна або неточна інформація про діяльність музею (Легеченко, 2009: 31).

На сьогоднішній час більшість регіональних музеїв не мають повноцінних сайтів, а обмежуються лише розміщенням загальної інформації про себе в мережі Інтернет, це пояснюється безліччю об'єктивних і суб'єктивних причин. У свою чергу великі центральні музеї України мають сайти, на яких опубліковані не тільки контактні дані музею, але й інформація про колекції та експозиції, також надається можливість замовити квитки не виходячи 3 дому і віртуально подорожувати по залах музею.

Актуальною проблемою багатьох музеїв України $\epsilon$ те, що вони використовують у діяльності і реєструють своє представництво у віртуальній мережі у вигляді сайтів-візиток. Це не відповідає сучасним вимогам, потрібно створювати динамічні ресурси, які були б конструктивними, естетичними, i функціональними, тому що відвідувач шукає повноцінного віртуального спілкування з музеями засобами Інтернет-технологій.

Творці та ідеологи формують завдання, які ставляться перед Інтернетджерелом в тому сенсі, щоб за сайтом зберігалися всі можливості реального музею. Виходячи із завдань сайту визначається загальне змістовне ядро вихідний масив інформації у вигляді перерахунку аспектів змісту, який в подальшому вимагає структурування. Кожен аспект в подальшому може стати окремим розділом. Основні завдання, які можна поставити перед сайтом музею наступні:

• загальна інформація про музей, як заклад; 
• довідкова інформація для потенційних відвідувачів;

• інформація про фонди та колекції музею;

- інформація про експозиції музею;

- інформація про проведення виставок в музеї та за його межами;

• інформація про екскурсії, які проводяться в музеї;

- інформація про лекції, семінари, заняття, консультації, майстер-класи, які проводяться співробітниками музеїв;

- інформація про святкові заходи, концерти, фестивалі, що проводяться на території музею, або під його патронатом;

- організація освітньо-ігрових програм;

- представлення освітньо-пізнавальних програм близьких до тематики музею;

• можливість зворотного зв'язку;

- інформація про наукові експедиції, що проводяться науковими співробітниками;

• зберігання оцифрованого матеріалу (Самаковска, 2010: 78).

Головна сторінка - це «обличчя» сайту, вона повинна бути яскравою i якісно ілюстрованою. На головній сторінці будь-якого музею має бути присутня зрозуміла навігаційна карта всієї структури ресурсу, основні розділи повинні розподілятися на підрозділи. Має бути створена можливість пошуку по сайту за ключовими словами. Ця опція дуже важлива, вона підвищує рейтинг музейного сайту. Потрапивши на головну сторінку, користувач повинен отримати коротку, але повну інформацію про музей в цілому. Центральний блок повинен бути виконаний у вигляді слайд-шоу, що дасть можливість миттєвого доступу до сторінок з описами основних колекцій музею. Завдяки мінливості цих рекламних картинок у музею буде можливість висвітлювати відразу кілька головних подій ( Гендина, Колкова, Алдохина, 2010: 100).

Найкраще це можна подивитися на прикладі Інтернет-джерела Національного музею історії України, на головній сторінці якого у верхній частині, «шапці», знаходиться слайдер, який транслює фото з проведених 
виставок, присутнє посилання на карту сайту, де за допомогою схеми показано всю структуру ресурсу. Це допомагає користувачеві в орієнтації, робить можливим швидкий доступ до будь-якого джерела. Розроблена електронна книга відгуків, де кожен бажаючий може написати повідомлення адміністрації музею, розміщенні контактні дані. У верхній панелі ресурсу можна змінити шифр тексту для зручності перегляду, а також, що важливо - це можливість перекладу тексту на англійську та українську мови без втрати змісту.

Житомирський обласний літературний музей має багаті фонди та цікаві експозиції, але зміст головної сторінки не дозволяє здогадатися про це тому, що тут розміщена тільки довідкова інформація для відвідувачів, відсутні яскраві фото експонатів в «шапці» сайту, a їх наявність та подання в динамічному вигляді заохочувала б бажаючих відвідати цей музей.

На головній сторінці викладаються основні новини, пов'язані 3 діяльністю музею. Для того щоб підтримувати сайт в актуальному стані, важливо оновлювати новинні блоки не менше трьох разів на тиждень. Приводами для публікації можуть стати відкриття виставок, захоплюючі майстер-класи, семінари чи конференції, конкурси або вікторини. Коли немає очевидного інформаційного приводу до створення контенту, можна розмістити анонс або цікаву історію про організацію, а часом просто написати про важливу пам'ятну дату або дні народження співробітників.

Часто значна частина головної сторінки відводиться для звернення офіційних осіб музею в більшості випадків - директорів, до відвідувачів. Так, на головній сторінці Національного музею історії України у Другій світовій війні, виділений окремий блок для звернення директора І.П. Ковальчука до відвідувачів із запрошенням відвідати музей, описані шляхи розвитку музею в майбутньому, розповідається про зв'язки музею з іншими йому подібними в Японії, США, Данії, Німеччині, Австрії, Шотландії.

На основі поставлених завдань вибудовується структура більшості музейних сайтів, що ділиться на наступні розділи: про музеї, постійна 
експозиція музею, виставки, освітні програми, наші послуги, для відвідувачів, для фахівців, видання та публікації, відео та фотогалерея, мультимедіа.

У розділі «Про музеї» представлена коротка історія створення установи, інформація про друзів і спонсорів музею, їхні контакти, надається інформація про культурну, наукову та просвітницьку роботу музею, публікації про музей, наявність філій (основні напрями діяльності та місце знаходження), нагороди. Найчастіше музеї надають дані по відділах і співробітниках за ієрархічною складовою - від начальника до простого співробітника. Зразком може бути Педагогічний музей України Національної академії педагогічних наук України. Цей музей у зв'язку з 110-річчям оформив інформацію у вигляді стендів і подав у хронологічній послідовності історію від заснування до сьогодення закладу.

У розділі «Виставки» виставляються на огляд поточні та архівні виставки, афіші, вони є тимчасовими і змінюються в міру настання тієї чи іншої події. Архів виставок може бути представлений у вигляді таблиці з поділом на рік, назву та межі проведення (Самаковська, 2012: 58).

Розділ «Експозиція» повинен містити не тільки загальну історичну довідку по пам'ятці, а також стати повноцінним джерелом для огляду і дослідження. Користувач, який входить в цей розділ повинен мати зручний пошуковий механізм розробленого електронного каталогу музейних предметів, щоб можна було знайти експонат, який зацікавив відвідувача за певними особливостями періодом, видом, авторами. Цей розділ сайту повинен бути детально продуманим в простоті використання його користувачами. Наприклад, якщо музей спеціалізується по мистецтву, то фото картин, скульптур, виробів 3 гончарства, повинні містити опис часу створення, автора або авторів. Необхідно мати можливість наблизити або повернути експонати для детального огляду. У цьому ж розділі має бути підрозділ «Нові надходження», де будуть представлені експонати, що надійшли за певний період (Легеченко, 2009: 31).

У розділі «Освітні програми» має бути представлена інформація про освітні проекти, які розробляються у співпраці з Міністерством освіти України 
для поглибленого вивчення школярами та студентами навчальних програм 3 історії, культурології, етнографії, української та зарубіжної літератури.

На Інтернет-ресурсі Чернігівського історичного музею імені В.В. Тарновського у відповідному розділі можна ознайомитися з розробками таких програм з історії військового мистецтва, адаптованих до освітніх програм вищої школи.

У розділі «Наші послуги» висвітлено комерційну діяльність музею. Тут публікується інформація про продаж квитків окремо для дорослих і дітей. Надаються дані по оплаті консультаційних послуг з питань, які є профільними для установи і проведенню експертиз культурних цінностей та з оформлення довідок по завершенні дослідження експонатів, що знаходяться в приватних зібраннях (Самаковська, 2012: 59). Окремим пунктом розписуються тарифи в музеї на дозвіл для копіювання рідкісних матеріалів, опублікованих праць наукових співробітників, користування літературою за науковим інтересом, якщо така $\epsilon$, передачі музейних експонатів для виставок, які знаходяться поза підпорядкуванням Міністерства культури України, оформлення інтер'єрів, фотографування і відеозйомку експозиції, використання для кіно-відеозйомки експонатів зі сховищ.

У розділі «Для відвідувачів» вміст у більшості випадків дублюється 3 вмістом розділу «Наші послуги», або в першому випадку йде загальна інформація, а в другому все детально розписано, окремо тільки може бути висвітлено режим роботи, контакти, карта проїзду до місця, де розташований музей.

Іноді музейні працівники викладають на огляд кошторис установи на виконання робіт на поточний рік, ця інформація розміщується в розділі «Для фахівців».

Розділ «Видання та публікації» має мати два підрозділи: друковані та електронні видання. Це можуть бути видання і публікації у вигляді каталогів, науково-методичних робіт по колекціях, по профільних проблемах, які досліджуються в музеях, довідники, путівник, посилання на архіви і корисні 
джерела. У віртуальних відвідувачів повинна бути можливість не тільки переглядати інформацію, але і завантажувати і в подальшомупрацювати з нею (Самаковська, 2010: 79).

Розділ «Фото і відеоматеріали» містить фото і відеозвіти 3 виставок, конференцій та проведених майстер-класів.

Розділ «Віртуальна екскурсія» на сайтах українських музеїв тільки починає впроваджуватися і поки що всі розробки знаходяться на початковому етапі. Нові технології постійно розвиваються і відкривають практично необмежені можливості для створення віртуального простору. Віртуальна екскурсія організована підбірка фото та відео зображень про видатні місця, іноді 3 текстовим або аудіо супроводом та засобами навігації (Матеріали із Вікіпедія: вільна енцикл., 2018). Можна створювати не тільки панорами 3 круговим оглядом залу, як, наприклад, це зроблено на сайті Національного історикоархеологічного заповідника «Кам'яна Могила», а взаємодіяти 3 предметами в цьому просторі, отримувати історичні довідки, як це діє на інформаційному ресурсі Національного музею-меморіалу жертв окупаційних режимів «Тюрма на Лонцького».

Висновки. Отже, єдиних вимог з формування інформаційного контенту i структури офіційного сайту музейної установи не існує. Разом 3 тим, враховуючи завдання, які ставляться перед Інтернет-джерелом вченими i суспільством формуються певні рекомендації, пов'язані з розробкою структури та змісту інформаційного контенту. Організація віртуального середовища повинна бути продумана до дрібниць, кожен дюйм екрану повинен бути заповнений цікавою, актуальною, достовірною інформацією, це дасть можливість у перспективі виховувати у громадян культуру спілкування, навчить аналізувати й обмірковувати різні типи джерел в мережі Інтернет. Проаналізувавши сайти музеїв України різних профілів і типів можна вказати на те, що поступово Інтернет-джерела приводять свою структуру та інформаційне середовище до єдиних європейських стандартів. Проведене дослідження показало ряд досягнень і недоліків контенту музейних Інтернет- 
ресурсів України. Позитивним зрушенням $є$ те, що музеї України починають впевнене інформаційне наповнення сайтів, створюють якісне, змістовне інформаційне середовище музею. Негативним залишається те, що часто порушується принцип логічності у структуруванні матеріалу; мають місце надмірність або, навпаки, неповнота представлених даних; різнорідність представленої інформації; невідповідність мови та стилю викладу інформації типам і рубриками сайту; наявність стилістичних помилок; надміру складне викладання інформації та одноманітність іï подачі; переважання тексту над ілюстраціями.

Існує ряд проблем з розвитком структури сайтів, якістю інформаційного наповнення ресурсу регіональних музеїв і деяких центральних установ, що в майбутньому потребує подальшого дослідження.

\section{СПИСОК ВИКОРИСТАНИХ ДЖЕРЕЛ І ЛІТЕРАТУРИ}

Віртуальна екскурсія [Електронний ресурс] // Вікіпедія: вільна енциклопедія. [Електронний ресурс]. Режим доступу: https://uk.wikipedia.org/wiki/\%D0\%92\%D1\%96\%D1\%80\%D1\%82\%D1\%83\%D0\% B0\%D0\%BB\%D1\%8C\%D0\%BD\%D0\%B0_\%D0\%B5\%D0\%BA\%D1\%81\%D0\%B A\%D1\%83\%D1\%80\%D1\%81\%D1\%96\%D1\%8F. Назва з екрана. Дата останньої правки: 24.08.2018.

Гендина, 2010 - Гендина Н. И., Колкова Н. И., Алдохина О. И. Создание эффективного официального сайта объекта культуры: от эмпирики к разработке и реализации научно обоснованной концепции // Вестник Кемеровского государственного университета культуры и искусств: журнал теоретических и прикладных исследований. 2010. С. 87-104.

Заславец, 2009 - Заславец Н. Н. Информационные технологии в музейной экспозиции // Справочник руководителя учреждения культуры. 2009. № 1. С. $65-72$.

Легеченко, 2009 - Легеченко М. В. Некоторые аспекты создания музейного веб-сайта // Мир науки, культуры, образования. 2009. №6. С. 30-32. 
Мина, 2016 - Мина Ж. Інформаційне представлення функціонування музеїв Львова в мережі Інтернет // Інформація, комунікація, суспільство 2016 : матеріали 5-ої Міжнародної наукової конференції ІКС-2016, 19-21 травня 2016 року, Україна, Львів, Славське / Національний університет «Львівська політехніка», Кафедра соціальних комунікацій та інформаційної діяльності. 2016. C. 326-327.

Самаковская, 2010 - Самаковская О.В.Моделирование контента сайта музея (на примере этнографических музеев и музеев-заповедников) // Вестник Кемеровского государственного университета культуры и искусств. 2010 . №12. C. $76-86$.

Самаковская, 2012 - Самаковская О.В.Формирование контента сайтов этнографических музеев: проблемы качественного представления музейной информации в Интернете и пути их решения // Вестник Кемеровского государственного университета культуры и искусств. 2012. №20. С. 55-61.

\section{REFERENCES}

Virtualna ekskursiia [Elektronnyi resurs] [Virtual excursion] // Vikipediia: vilna entsykl. [Elektronnyi resurs]. Rezhym dostupu: https://uk.wikipedia.org/wiki/\%D0\%92\%D1\%96\%D1\%80\%D1\%82\%D1\%83\%D0\% B0\%D0\%BB\%D1\%8C\%D0\%BD\%D0\%B0_\%D0\%B5\%D0\%BA\%D1\%81\%D0\%B A\%D1\%83\%D1\%80\%D1\%81\%D1\%96\%D1\%8F. Nazva z ekrana. Data ostannoi pravky : 24.08.2018. [in Ukrainian].

Gendina, 2010 - Gendina N. I., Kolkova N. I., Aldohina O. I. Sozdanie effektivnogo ofitsialnogo sayta ob'ekta kulturyi: ot empiriki k razrabotke i realizatsii nauchno obosnovannoy kontseptsii [Creation of an effective official site of the cultural object: from the empiricists to the development and implementation of a scientifically sound concept] // Vestnik Kemerovskogo gosudarstvennogo universiteta kulturyi i iskusstv: zhurnal teoreticheskih i prikladnyih issledovaniy. 2010. S. 87-104. [in Russian]. 
Zaslavets, 2009 - Zaslavets N.N. Informatsionnyie tehnologii v muzeynoy ekspozitsii [Information technologies in the museum exposition] // Spravochnik rukovoditelya uchrezhdeniya kulturyi. 2009. № 1. S. 65-72. [in Russian].

Legechenko, 2009 - Legechenko M.V. Nekotoryie aspektyi sozdaniya muzeynogo veb-sayta [Some aspects of creating a museum website] // Mir nauki, kulturyi, obrazovaniya. 2009. № 6. S. 30-32. [in Russian].

Myna, 2016 - Myna Zh. Informatsiine predstavlennia funktsionuvannia muzeiv Lvova v merezhi Internet [Informational representation of the functioning of Lviv museums on the Internet] // Informatsiia, komunikatsiia, suspilstvo 2016 : materialy 5-oi Mizhnarodnoi naukovoi konferentsii IKS-2016, 19-21 travnia 2016 roku, Ukraina, Lviv, Slavske / Natsionalnyi universytet «Lvivska politekhnika», Kafedra sotsialnykh komunikatsii ta informatsiinoi diialnosti. 2016. S. 326-327. [in Ukrainian].

Samakovskaya, 2010 - Samakovskaya O.V. Modelirovanie kontenta sayta muzeya (na primere etnograficheskih muzeev i muzeev-zapovednikov) [Modelization of the content of the museum site (on the example of ethnographic museums and museum-reserves)] // Vestnik Kemerovskogo gosudarstvennogo universiteta kulturyi i iskusstv. 2010. № 12. S. 76-86. [in Russian].

Samakovskaya, 2012 - Samakovskaya O.V. Formirovanie kontenta saytov etnograficheskih muzeev: problemyi kachestvennogo predstavleniya muzeynoy informatsii v Internete i puti ih resheniya [Formation of the content of the sites of ethnographic museums: problems of the quality presentation of museum information on the Internet and ways of their solution]// Vestnik Kemerovskogo gosudarstvennogo universiteta kulturyi i iskusstv. 2012. № 20. S. 55-61. [in Russian]. 